\title{
Carcass and body organ characteristics of broilers supplemented with dietary sodium and sodium salts under a phase feeding system
}

\author{
Mirza Muhammad Haroon Mushtaq", Rana Parvin and Jihyuk Kim
}

\begin{abstract}
The effect of sodium and sodium salts on carcass and body organ characteristics of broilers under a four phase feeding program were investigated. A basal diet $(0.08 \% \mathrm{dNa}$ with $\mathrm{NaCl})$ was formulated and one of two sources of $\mathrm{dNa}\left(\mathrm{NaHCO}_{3}\right.$ and $\left.\mathrm{Na}_{2} \mathrm{SO}_{4}\right)$ were supplemented to obtain four different percentages of $\mathrm{dNa}(0.17,0.26,0.35$, and $0.44 \%)$ for each treatment. There was a linear decrease in dressing percentage (DP) with source $\times$ level interaction $(p \leq 0.001)$, while there was a linear increase in breast yield and thigh yield with increasing $\mathrm{dNa}$ supplementation ( $p \leq 0.001$ ). Chicks fed $0.35 \% \mathrm{NaHCO}_{3}$ and $0.44 \% \mathrm{dNa} \mathrm{Na}_{2} \mathrm{SO}_{4}$ supplemental salts had lower abdominal fat $(p \leq 0.04)$. Chicks that received increasing levels of $\mathrm{dNa}$ (from 0.17 to $0.44 \%$ ) showed increasing gizzard weight $(p \leq 0.002)$ and decreasing spleen weight $(\mathrm{p} \leq 0.02)$. When both salts were supplemented at $0.26 \% \mathrm{dNa}$, the chicks showed their lowest bursa weight $(p \leq 0.001)$. Consequently, chicks at higher dNa showed an increase in breast and thigh meat yield, and increasing capacity of their digestive organ. The higher levels of dNa should be tested with other cations and anions to fully understand acid base homoeostasis.
\end{abstract}

Keywords: Sodium, Salt, Carcass and body organ characteristics, Phase feeding program, Broiler

\section{Introduction}

Sodium $\left(\mathrm{Na}^{+}\right)$, the principal cation of extracellular fluid, is involved in numerous functions including the regulation of extracellular fluid volume, acid base balance, cell membrane potential, nerve function, and the absorption of glucose and amino acids ([1]; Leeson and Summers, [2]). Dietary $\mathrm{Na}(\mathrm{dNa})$ and chloride $(\mathrm{Cl})$ are inexpensive in terms of meeting dietary requirements, as Pakistan has huge reserves of sodium chloride $(\mathrm{NaCl})$ [3].

Mongin [1] described the effect and interrelationship of $\mathrm{Na}^{+}, \mathrm{K}^{+}$, and $\mathrm{Cl}^{-}$in an equation for dietary electrolyte balance $(\mathrm{DEB}=\mathrm{Na}+\mathrm{K}-\mathrm{Cl}, \mathrm{mEq} / \mathrm{kg}$ diet $)$. Rondon et al. [4] and Borges et al. [5] reported different DEB values with different concentrations of $\mathrm{Na}^{+}, \mathrm{K}^{+}$, or $\mathrm{Cl}^{-}$. Recently, Mushtaq et al. [6,7] tested 3 levels of $\mathrm{dNa}$ and $\mathrm{dCl}$ adjusted with $\mathrm{dK}$ and reported that different ions acted differently to yield a similar DEB of $250 \mathrm{mEq} / \mathrm{kg}$. The addition of various salts changes osmotic balance by

\footnotetext{
* Correspondence: haroonuaf@gmail.com

Poultry Science Division, National Institute of Animal Science, RDA, 114 Sinbang 1-gil, Seonghwan-eup, Seobuk-gu, Cheonan-si, Chungcheongnam-do 331-801, Republic of Korea
}

contributing electrolytes [5,8-10]. Most researchers consider Na-bicarbonate $\left(\mathrm{NaHCO}_{3}\right)$ as the best supplemental salt for $\mathrm{Na}^{+}$and $\mathrm{HCO}_{3}^{-}$[11-16]. Sodium sulphate $\left(\mathrm{Na}_{2} \mathrm{SO}_{4}\right)$ induced severe blood acidosis when it was compared with other sulphate sources in growth trials; hence it was suggested that the acidic properties of sulphates are directly linked to supplemental salts $[16,17]$.

A significant effect of temperature on abdominal fat was found for treatments $\left(5 \% \mathrm{KCl}\right.$ or $5 \% \mathrm{NaHCO}_{3}$ in water) under normal but not under cyclic environmental conditions [18]. Sharma and Gangwar [8] reported a decrease in the concentration of $\mathrm{Na}^{+}$and $\mathrm{K}^{+}$in the breast and thigh muscles of broilers from 4 to 8 wks old under high temperature $\left(32^{\circ} \mathrm{C}\right)$. The author, moreover, observed that breast muscles had significantly lower $\mathrm{Na}^{+}$and higher $\mathrm{K}^{+}$concentrations than thigh muscles. Pourreza and Edriss [19] reared straight-run broilers at $20^{\circ} \mathrm{C}$ or $30^{\circ} \mathrm{C}$ and noticed that the high temperature decreased slaughter, carcass, and abdominal fat weight and increased dressing percentage. Johnson and Karunajeewa [11], Karunajeewa et al. [20], and 
Borges et al. [21] observed no effect on carcass and abdominal fat yield under different DEB treatments under normal environmental condition.

The development of housing systems and genetics has necessitated a look into the changing nutrient requirements of current broilers. The present study evaluated the effect of dietary sodium supplementation with the applicability of DEB using different sodium salts on carcass and body organ characteristics of a modern broiler strain fed under a four phase feeding program.

\section{Materials and methods}

All experimental birds and procedures were maintained in compliance with laws proposed by the Advanced Studies and Research Board, University of Veterinary and Animal Sciences, Lahore, Pakistan.

\section{Birds' husbandry}

A total of 1280 day-old straight-run Hubbard broiler chicks (Hubbard $\times$ Hubbard) were given one of eight dietary treatments replicated four times; under this system each replicate contained 40 birds (without considering the sex). Each replicate pen was equipped with a separate overhead, transparent, and volume-graduated $20 \mathrm{~L}$ water bottle linked to a nipple drinker line. Water bottles were cleaned and filled with fresh water on a daily basis. One flat bottom round feeder was provided for each experimental pen. Birds were housed in environment control systems where variation in temperature and relative humidity were recorded and maintained according to the production manual [22]. Continuous light was provided $24 \mathrm{~h}$ for the first 3 days and then a $23 \mathrm{~L}: 1 \mathrm{D}$ light pattern was adopted for the rest of the experimental period. Fresh sawdust $(7.5 \mathrm{~cm}$ deep) was used as litter material over a concrete floor. For the first 3 days, the house temperature was maintained at $32^{\circ} \mathrm{C}$ and thereafter reduced by $0.5^{\circ} \mathrm{C}$ per day until $24^{\circ} \mathrm{C}$ was attained at $\mathrm{d} 19$.

Birds were vaccinated against Newcastle Disease (ND) plus Infectious Bronchitis viruses at $4 \mathrm{~d}$, Infectious Bursal Disease virus at $8 \mathrm{~d}$ and again at $14 \mathrm{~d}$; Hydropericardium Syndrome virus at $18 \mathrm{~d}$, and ND-Lasota strain at $\mathrm{d} 22$.

\section{Dietary plan and experimental design}

A basal diet with $\mathrm{dNa}, \mathrm{K}$ and $\mathrm{Cl}$ at $0.08,0.71$, and $0.20 \%$, respectively, with a DEB value of $160 \mathrm{mEq} / \mathrm{kg}$ (Table 1 and Table 2) was formulated. For this purpose, a large batch of basal diet was prepared for each phase and then experimental diets were prepared such that four levels of $\mathrm{dNa}(0.17,0.26,0.35$, and $0.44 \%)$ were supplemented to this basal diet with either commercially available feedgrade sodium bicarbonate $\left(\mathrm{NaHCO}_{3}\right)$ or sodium sulphate $\left(\mathrm{Na}_{2} \mathrm{SO}_{4}\right)$. The levels of $\mathrm{dNa}$ corresponded to $\mathrm{DEB}$ values of 200, 240, 280, and $320 \mathrm{mEq} / \mathrm{kg}$, respectively. The
Table 1 Ingredient composition of basal diets fed four levels of sodium with two sources of sodium salts at different stages of growth in broilers ${ }^{1)}$

\begin{tabular}{lcccc}
\hline Ingredients (\%) & $\begin{array}{c}\text { Pre-starter } \\
(\mathbf{1} \mathbf{- 1 0} \mathbf{~ d )}\end{array}$ & $\begin{array}{c}\text { Starter } \\
(\mathbf{1 1} \mathbf{- 2 0} \mathbf{~ d )}\end{array}$ & $\begin{array}{c}\text { Grower } \\
(\mathbf{2 1} \mathbf{- 3 3} \mathbf{~})\end{array}$ & $\begin{array}{c}\text { Finisher } \\
(\mathbf{3 4} \mathbf{- 4 2} \mathbf{~ d )}\end{array}$ \\
\hline Corn & 46.93 & 47.54 & 67.46 & 67.94 \\
Broken rice & 13.46 & 16.16 & 0.07 & - \\
Soybean meal & 27.63 & 29.11 & 26.93 & 24.47 \\
Canola Meal & 6.39 & 1.24 & - & - \\
Oil $\left.{ }^{2}\right)$ & 1.62 & 2.21 & 1.88 & 3.94 \\
DCP & 2.16 & 2.02 & 1.89 & 1.60 \\
Limestone & 1.04 & 0.94 & 1.05 & 1.10 \\
L-Lysine HCl & 0.23 & 0.22 & 0.20 & - \\
L-Lysine sulphate & - & - & - & 0.34 \\
NaCl & 0.15 & 0.16 & 0.16 & 0.16 \\
KCl & 0.04 & 0.03 & 0.05 & 0.14 \\
DL-methionine & 0.20 & 0.20 & 0.17 & 0.17 \\
L-threonine & 0.05 & 0.07 & 0.03 & 0.04 \\
Premix ${ }^{3)}$ & 0.10 & 0.10 & 0.10 & 0.10 \\
\hline
\end{tabular}

${ }^{1)}$ All diets were supplemented with four levels of either $\mathrm{NaHCO}_{3}(0.33,0.66$, 0.99 , or $1.32 \%)$ or $\mathrm{Na}_{2} \mathrm{SO}_{4}(0.28,0.56,0.84$, or $1.12 \%)$ to make final $\mathrm{Na}$ concentrations of $0.17,0.26,0.35$, or $0.44 \%$, respectively. The basal diet contained $0.08 \% \mathrm{Na}$.

${ }^{2)}$ Residual bakery oil.

3) Provides per kg of finished diet: vitamin $A, 12 \mathrm{mg}$; vitamin $D_{3}, 7 \mathrm{mg}$; vitamin $E$, $100 \mathrm{mg}$; vitamin $\mathrm{K}_{3}$ (50\% as MNB), $3 \mathrm{mg}$; vitamin $\mathrm{B}_{1}(98 \%), 3 \mathrm{mg}$; vitamin $\mathrm{B}_{2}$ $(800,000 \mathrm{mg}), 12 \mathrm{mg}$; vitamin $B_{3}$ (niacin; $\left.99 \%\right), 600 \mathrm{mg}$; vitamin $B_{6}(98 \%), 4 \mathrm{mg}$; vitamin $\mathrm{B}_{9}$ (folic acid; 95\%), 2 mg; vitamin $\mathrm{B}_{12}(0.10 \%), 20 \mathrm{mg}$; biotin $(0.10 \%)$, $5 \mathrm{mg}$; Ca-Pentothenate (98\%), $12 \mathrm{mg}$; cholin (70\% as choline sodium), $1 \mathrm{~g}$; $\mathrm{MnO}$ (60\%), 169 mg; $\mathrm{FeSO}_{4}$ (21\%), 200 mg; ZnSO 4 (36\%), 150 mg; CuSO 4 (25\%), 40 mg; Se (sodium selenite $0.40 \%), 100 \mathrm{mg}$; KI (68\%), 2 mg; salinomycin, $60 \mathrm{mg}$; zinc bacitracin (as Albac 10\%), $50 \mathrm{mg}$.

experimental period was divided into four phases: prestarter ( 1 to $10 \mathrm{~d})$, starter (11 to $20 \mathrm{~d})$, grower $(21$ to $33 \mathrm{~d}$ ), and finisher ( 34 to $42 \mathrm{~d}$ ) which met or exceeded the nutrient specifications recommended by the Hubbard management guide ([22]; Table 2) except for amino acid composition.

All ingredients were assayed for their proximate composition [23] prior to diet formulation and actual values were used in the formulation. The $\mathrm{Na}^{+}$and $\mathrm{K}^{+}$contents of each diet were analyzed by flame photometer [23] and $\mathrm{Cl}^{-}$content was analyzed by titration with $\mathrm{AgNO}_{3}^{-}[24]$. Prior to starting the experiment, the $\mathrm{Na}^{+}, \mathrm{K}^{+}$, and $\mathrm{Cl}^{-}$ contents of the final diet were verified. The $\mathrm{ME}$ of each ingredient was calculated by the appropriate regression equation suggested by the NRC [25]. The amino acid composition of each ingredient was calculated using AminoDat $^{\mathrm{TM}}$ 3.0 Platinum (Degussa AG, Germany) based on the DM and CP contents of each ingredient [6]. The amino acid composition of each diet met or exceeded the ideal amino acid ratio suggested by Han and Baker [26]. The experiment, offering mash diets, lasted until $42 \mathrm{~d}$ of age. 
Table 2 Nutrient composition of basal diets for different phases of birds fed four levels of sodium with two sources of sodium salts ${ }^{1)}$

\begin{tabular}{lcccc}
\hline Nutrients & $\begin{array}{c}\text { Pre-starter } \\
(\mathbf{1} \mathbf{- 1 0} \mathbf{~ d )}\end{array}$ & $\begin{array}{c}\text { Starter } \\
\mathbf{( 1 1} \mathbf{- 2 0} \mathbf{~ d )}\end{array}$ & $\begin{array}{c}\text { Grower } \\
\mathbf{( 2 1} \mathbf{- 3 3} \mathbf{~ d )}\end{array}$ & $\begin{array}{c}\text { Finisher } \\
\mathbf{( 3 4} \mathbf{- 4 2} \mathbf{~ d )}\end{array}$ \\
\hline ME (kcal/kg) & 2900 & 3000 & 3000 & 3147 \\
Crude Protein (\%) & 21.00 & 20.00 & 19.00 & 18.00 \\
Calcium (\%) & 1.00 & 0.90 & 0.90 & 0.85 \\
Available Phos. (\%) & 0.45 & 0.42 & 0.40 & 0.35 \\
Sodium (\%) & 0.08 & 0.08 & 0.08 & 0.08 \\
Potassium (\%) & 0.71 & 0.71 & 0.71 & 0.71 \\
Chloride (\%) & 0.20 & 0.20 & 0.20 & 0.20 \\
DEB ${ }^{2)}$ (mEq/kg) & 160 & 160 & 160 & 160 \\
Dig Lys (\%) & 1.10 & 1.05 & 0.97 & 0.93 \\
Dig Met/Dig Lys & 0.45 & 0.45 & 0.44 & 0.44 \\
Dig Met + Dig & 0.72 & 0.71 & 0.72 & 0.72 \\
Cys/Dig Lys (\%) & & & & \\
Dig Thr/Dig Lys & 0.66 & 0.67 & 0.66 & 0.66 \\
Dig Try/Dig Lys & 0.18 & 0.18 & 0.18 & 0.17 \\
\hline
\end{tabular}

${ }^{1)} \mathrm{NaHCO}_{3}$ and $\mathrm{Na}_{2} \mathrm{SO}_{4}$.

${ }^{2)}$ Dietary Electrolyte Balance $(\mathrm{mEq} / \mathrm{kg})=(\% \mathrm{Na} \times 10,000 / 23)+(\% \mathrm{~K} \times 10,000 / 39.1)-$ (\% $\mathrm{Cl} \times 10,000$ / 35.5).

\section{Growth response}

Feed intake (FI; g/bird), BW gain (BWG; g/bird) and feed-to-gain ratio (FG; g:g) were recorded at the end of the experiment. The feed was withheld for $6 \mathrm{~h}$ before weighing the birds to ensure the emptying of the digestive tract of the bird. Mortality was recorded on a daily basis and dead bird was weighed prior to removal to correct FG.

\section{Carcass and organ characteristics}

At the end of $42 \mathrm{~d}$, two birds were randomly selected from each replicate and subjected to carcass and body organ evaluation. The feed was withheld for $6 \mathrm{~h}$ before slaughter to ensure emptying of the digestive tract. Carcass and body organ responses were evaluated in terms of dressing percentage, breast, thigh, abdominal fat, gizzard, proventriculus, heart, liver, kidney, spleen, pancreas, bursa, gallbladder, intestine, and lung weights, and for the shank and intestine lengths (Table 3 and Table 4). The carcass and body organ weights were taken on a fresh basis. Dressing percentage (DP) was calculated by dividing dressed weight, without viscera, by live weight and multiplied by 100 . The weight of the abdominal fat pad was expressed as DP (without visceral weight), while the weights of other body organs (gizzard, proventriculus, heart, liver, kidney, spleen, pancreas, bursa, gall bladder, lungs, and intestine) were taken as a percentage of dressing weight (with visceral weight). Intestinal length was measured (in centimeters) from the start of the duodenal loop to the ileocaecal junction [27].
Table 3 Effect of dietary sodium and sodium salts on growth performance of broilers on day

\begin{tabular}{|c|c|c|c|}
\hline Item & $\begin{array}{l}\text { BW gain } \\
\text { (g/bird) }\end{array}$ & $\begin{array}{l}\text { Feed intake } \\
\text { (g/bird) }\end{array}$ & $\begin{array}{l}\text { Feed:gain } \\
\text { (g:g) }\end{array}$ \\
\hline \multicolumn{4}{|l|}{ Dietary Na (\%) } \\
\hline 0.17 & 1,893 & 3,564 & 1.95 \\
\hline 0.26 & 1,959 & 3,634 & 1.80 \\
\hline 0.35 & 1,883 & 3,605 & 1.89 \\
\hline 0.44 & 1,864 & 3,622 & 1.95 \\
\hline SEM & 30.5 & 45.9 & 0.076 \\
\hline \multicolumn{4}{|l|}{ Salts } \\
\hline $\mathrm{NaHCO}_{3}$ & 1,884 & 3,604 & 1.88 \\
\hline $\mathrm{Na}_{2} \mathrm{SO}_{4}$ & 1,916 & 3,608 & 1.91 \\
\hline SEM & 21.6 & 32.4 & 0.053 \\
\hline \multicolumn{4}{|l|}{$\mathrm{Na} \times$ Salts } \\
\hline $0.17 \times \mathrm{NaHCO}_{3}$ & 1,941 & 3,586 & 1.82 \\
\hline $0.26 \times \mathrm{NaHCO}_{3}$ & 1,941 & 3,631 & 1.83 \\
\hline $0.35 \times \mathrm{NaHCO}_{3}$ & 1,829 & 3,649 & 1.91 \\
\hline $0.44 \times \mathrm{NaHCO}_{3}$ & 1,824 & 3,551 & 1.98 \\
\hline $0.17 \times \mathrm{Na}_{2} \mathrm{SO}_{4}$ & 1,844 & 3,542 & 2.08 \\
\hline $0.26 \times \mathrm{Na}_{2} \mathrm{SO}_{4}$ & 1,977 & 3,637 & 1.76 \\
\hline $0.35 \times \mathrm{Na}_{2} \mathrm{SO}_{4}$ & 1,936 & 3,560 & 1.88 \\
\hline $0.44 \times \mathrm{Na}_{2} \mathrm{SO}_{4}$ & 1,905 & 3,694 & 1.91 \\
\hline SEM & 43.1 & 64.9 & 0.107 \\
\hline ANOVA & --——- & - Probability - & -——— \\
\hline $\mathrm{Na}$ & NS & NS & NS \\
\hline $\mathrm{Na}_{\llcorner}$ & NS & NS & NS \\
\hline $\mathrm{Na}_{\mathrm{Q}}$ & NS & NS & NS \\
\hline Salt & NS & NS & NS \\
\hline Salt $\times \mathrm{Na}$ & 0.036 & NS & NS \\
\hline
\end{tabular}

NS - Non-significant.

$\mathrm{Na}_{\mathrm{L}}$ and $\mathrm{Na}_{\mathrm{Q}}$ are linear and quadratic terms for $\mathrm{Na}$, respectively.

\section{Water characteristics}

Water alters carcass responses because of its concentrations of electrolytes $\left(\mathrm{Na}^{+}, \mathrm{K}^{+}\right.$and $\left.\mathrm{Cl}^{-}\right)$; therefore, supplied water was analyzed for these electrolytes. Water characteristics were also recorded twice (morning and noon) daily to check $\mathrm{pH}$ by $\mathrm{pH}$ meter (LT-Lutron $\mathrm{pH}$ 207 Taiwan) and dissolved oxygen by DO meter (DO; YSI 55 Incorporated, Yellow Springs, Ohio, 4387, USA). Moreover, temperature, electrical conductivity (EC), total dissolved solids (TDS), and salinity were recorded by the Combo meter (H M Digital, Inc. CA 90230; Table 5). These observations were randomly recorded from different replicates.

\section{Statistical analyses}

The experiment was executed under a completely randomized design with factorial arrangement using four 
Table 4 Effect of dietary sodium and sodium salts on carcass and body organ responses of broilers

\begin{tabular}{|c|c|c|c|c|c|}
\hline Item & Dressing weight ${ }^{1)}$ & Breast weight $^{2)}$ & Thigh weight $^{2)}$ & Intestinal weight $^{3)}$ & Abdominal fat $^{1)}$ \\
\hline \multicolumn{6}{|l|}{ Dietary Na (\%) } \\
\hline 0.17 & 56.12 & 31.85 & 45.26 & 58.2 & 3.01 \\
\hline 0.26 & 54.18 & 32.98 & 46.28 & 54.3 & 3.12 \\
\hline 0.35 & 52.94 & 33.79 & 47.34 & 54.9 & 2.44 \\
\hline 0.44 & 52.07 & 34.31 & 48.30 & 56.1 & 2.61 \\
\hline SEM & 0.423 & 0.347 & 0.627 & 1.15 & 0.24 \\
\hline \multicolumn{6}{|l|}{ Salts } \\
\hline $\mathrm{NaHCO}_{3}$ & 53.95 & 33.16 & 46.28 & 56.3 & 2.74 \\
\hline $\mathrm{Na}_{2} \mathrm{SO}_{4}$ & 53.70 & 33.30 & 47.31 & 55.4 & 2.84 \\
\hline SEM & 0.299 & 0.246 & 0.443 & 0.81 & 0.17 \\
\hline \multicolumn{6}{|l|}{$\mathrm{Na} \times$ Salts } \\
\hline $0.17 \times \mathrm{NaHCO}_{3}$ & 55.68 & 32.11 & 45.29 & 58.8 & 2.96 \\
\hline $0.26 \times \mathrm{NaHCO}_{3}$ & 54.85 & 32.56 & 45.05 & 56.2 & 2.93 \\
\hline $0.35 \times \mathrm{NaHCO}_{3}$ & 53.38 & 33.57 & 46.79 & 58.7 & 1.93 \\
\hline $0.44 \times \mathrm{NaHCO}_{3}$ & 51.90 & 34.40 & 48.01 & 51.6 & 3.12 \\
\hline $0.17 \times \mathrm{Na}_{2} \mathrm{SO}_{4}$ & 56.56 & 31.60 & 45.24 & 57.7 & 3.06 \\
\hline $0.26 \times \mathrm{Na}_{2} \mathrm{SO}_{4}$ & 53.50 & 33.40 & 47.51 & 52.4 & 3.31 \\
\hline $0.35 \times \mathrm{Na}_{2} \mathrm{SO}_{4}$ & 52.51 & 34.01 & 47.90 & 51.1 & 2.94 \\
\hline $0.44 \times \mathrm{Na}_{2} \mathrm{SO}_{4}$ & 52.24 & 34.22 & 48.58 & 60.7 & 2.11 \\
\hline SEM & 0.599 & 0.492 & 0.886 & 1.62 & 0.35 \\
\hline ANOVA & \multicolumn{5}{|c|}{ 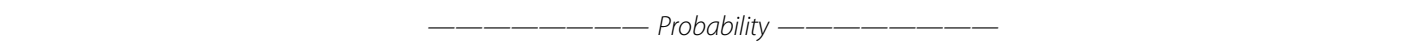 } \\
\hline $\mathrm{Na}$ & $\leq 0.001$ & $\leq 0.001$ & 0.008 & NS & NS \\
\hline $\mathrm{Na}_{\mathrm{L}}$ & $\leq 0.001$ & $\leq 0.001$ & $\leq 0.001$ & NS & NS \\
\hline $\mathrm{Na}_{\mathrm{Q}}$ & NS & NS & NS & 0.03 & NS \\
\hline Salt & NS & NS & NS & NS & NS \\
\hline Salt $\times \mathrm{Na}$ & NS & NS & NS & $\leq 0.001$ & 0.04 \\
\hline
\end{tabular}

NS - Non-significant.

${ }^{1)} \%$ of live weight (without visceral organs).

2) $\%$ of dressed weight (with organs weights).

${ }^{3)}$ measured in grams.

$\mathrm{Na}_{\llcorner}$and $\mathrm{Na}_{\mathrm{Q}}$ are linear and quadratic terms for $\mathrm{Na}$, respectively.

levels of $\mathrm{dNa}$ from two salt sources. The experimental pen was an experimental unit. The data obtained at the end of the experiment were subjected to ANOVA using GLM of Minitab 15.1 (Minitab Inc., State College PA). A statistical significance of 0.05 was used unless stated otherwise.

\section{Results and discussion}

Water was evaluated on a daily basis for quality parameters including temperature, $\mathrm{pH}, \mathrm{EC}, \mathrm{TDS}, \mathrm{DO}$, and salinity (Table 5). At the start of the experiment, water was also analyzed for its sodium absorption ratio (25.6) and residual sodium carbonate (9.02). As the concentration of various minerals (cations plus anions) and values of other quality parameters in drinking water could alter the electrolyte concentration of digesta $([12,28]$; b) their concentration in water was evaluated. The water electrolyte concentration was too low to impact carcass and organ yields. Water $\mathrm{pH}$ values $(7.17-7.49)$ were within the range (6.0-8.5) considered optimal for broiler performance [28-30]. Previous reports [31,32] showed retarded growth up to a $\mathrm{pH}$ level of 6.3. The water TDS level ranged from 1000-3000 ppm was considered satisfactory for broilers by Chiba [33], however the analyzed values i.e. 10601284 did not appear to disturb the present experiment.

All growth responses were unaffected by dietary treatments, except for sodium level and salt interaction on $\mathrm{BW}$ gain (BWG; $\mathrm{p} \leq 0.036$; Table 3 ). The supplementation of $\mathrm{Na}_{2} \mathrm{SO}_{4}$ at $0.26 \%$ showed higher BWG at day 42 . However this change in BWG was not sufficient to positively influence feed:gain (FG).

Carcass and intestinal responses were affected by supplementation of $\mathrm{dNa}$ from $\mathrm{NaHCO}_{3}$ and $\mathrm{Na}_{2} \mathrm{SO}_{4}$ (Table 4). A highly linear drop in DP $(\mathrm{p} \leq 0.001)$ was observed with 
Table 5 Drinking water properties during the experimental period

\begin{tabular}{llcccccc}
\hline Phase & Item & Salinity & TDS $^{\mathbf{1}}$ & $\mathbf{E C}^{\mathbf{2}}$ & Temperature & $\mathbf{p H}$ & $\mathbf{D O}^{\mathbf{3}}$ \\
\hline Phase 1 & Max & 1.30 & 1284 & 1.39 & 29.7 & 7.49 & 5.40 \\
& Min & 1.20 & 1198 & 1.27 & 26.2 & 7.31 & 3.90 \\
& Average & 1.25 & 1251 & 1.32 & 27.3 & 7.40 & 4.65 \\
Phase 2 & Max & 1.20 & 1111 & 1.21 & 26.4 & 7.35 & 5.07 \\
& Min & 1.20 & 1060 & 1.06 & 25.8 & 7.17 & 3.70 \\
& Average & 1.20 & 1088 & 1.12 & 26.0 & 7.27 & 4.39 \\
Phase 3 & Max & 1.30 & 1187 & 1.24 & 25.2 & 7.40 & 5.60 \\
& Min & 1.20 & 1108 & 1.08 & 24.3 & 7.21 & 3.70 \\
& Average & 1.22 & 1144 & 1.15 & 24.9 & 7.33 & 4.65 \\
Phase 4 & Max & 1.20 & 1194 & 1.21 & 24.8 & 7.33 & 5.07 \\
& Min & 1.20 & 1110 & 1.07 & 24.0 & 7.23 & 3.70 \\
& Average & 1.20 & 1141 & 1.11 & 24.2 & 7.29 & 4.39 \\
\hline
\end{tabular}

${ }^{1)}$ TDS - Total Dissolved Solids.

${ }^{2)} \mathrm{EC}$ - Electric Conductivity.

${ }^{3)} \mathrm{DO}$ - Dissolved Oxygen.

Salinity, TDS, EC, temperature, and DO were measured as parts per thousand (ppt), parts per million (PPM), millisemen/centimeter $(\mathrm{mS} / \mathrm{cm})$, centigrade $\left({ }^{\circ} \mathrm{C}\right)$ and milligram/litre $(\mathrm{mg} / \mathrm{L})$, respectively.

increasing supplementation of dNa. Mushtaq et al. [7] observed no difference in DP with increasing $\mathrm{dNa}$ from 0.20 to $0.30 \%$. Their difference in results might be due to the lower levels of $\mathrm{dNa}$ studied. Salt sources or interaction effects in the present study were not beneficial on DP per se. Breast $(\mathrm{p} \leq 0.001)$ and thigh $(\mathrm{p} \leq 0.001)$ meat yield increased with increasing supplementation of $\mathrm{dNa}$ (Table 4). This contradiction in results might be due the measurement of breast and thigh meat as a percent of dressing weight with organs. These findings were not in line with the results of Mushtaq et al. [7] who observed reduced breast and leg meat by increasing $\mathrm{dNa}$ from 0.20 to $0.30 \%$. This difference could be due to heat stress conditions in their experiment as more nutrients, consumed to maintain acid base balance, may not be converted to meat.

The abdominal fat pad was affected with source $\times$ level interaction (Table 6). The abdominal fat pad was lowest at $0.35 \% \mathrm{dNa}$ in diets supplemented with $\mathrm{NaHCO}_{3}$. A similar response of abdominal fat to a high level of $\mathrm{dNa}$ $(0.30 \%)$ was observed by Mushtaq et al. [7]. In the present study, increasing $\mathrm{dNa}$ under normal physiological conditions did not disturb basal metabolism and energy was mainly utilized for meat production and not wasted as abdominal fat.

The interaction (level $\times$ source) effect was found to change intestinal weight $(\mathrm{p} \leq 0.001)$; the lowest weight $(51.6$ vs. $51.1 \mathrm{gm})$ was recorded at $0.44 \%\left(\mathrm{NaHCO}_{3}\right)$ and $0.35 \% \mathrm{dNa}\left(\mathrm{Na}_{2} \mathrm{SO}_{4}\right)$. Intestinal weight reflects the gut's capacity to absorb nutrients, which reflects better health; therefore, higher levels of $\mathrm{dNa}$ showed a lower carcass yield.
Table 6 Effect of dietary sodium and sodium salts on body organ weights of broilers at the end of the experiment

\begin{tabular}{|c|c|c|c|c|}
\hline Item & Gizzard & Kidney & Spleen & Bursa \\
\hline & \multicolumn{4}{|c|}{ ————— \% of dressed weight ${ }^{1)}$ ———— } \\
\hline \multicolumn{5}{|l|}{ Dietary Na (\%) } \\
\hline 0.17 & 2.41 & 0.31 & 0.13 & 0.23 \\
\hline 0.26 & 2.57 & 0.36 & 0.08 & 0.15 \\
\hline 0.35 & 2.98 & 0.37 & 0.07 & 0.21 \\
\hline 0.44 & 2.99 & 0.37 & 0.08 & 0.25 \\
\hline SEM & 0.15 & 0.02 & 0.02 & 0.02 \\
\hline \multicolumn{5}{|l|}{ Salts } \\
\hline $\mathrm{NaHCO}_{3}$ & 2.85 & 0.42 & 0.09 & 0.21 \\
\hline $\mathrm{Na}_{2} \mathrm{SO}_{4}$ & 2.62 & 0.28 & 0.09 & 0.22 \\
\hline SEM & 0.10 & 0.02 & 0.01 & 0.0 \\
\hline \multicolumn{5}{|l|}{$\mathrm{Na} \times$ Salts } \\
\hline $0.17 \times \mathrm{NaHCO}_{3}$ & 2.72 & 0.42 & 0.11 & 0.16 \\
\hline $0.26 \times \mathrm{NaHCO}_{3}$ & 2.65 & 0.47 & 0.10 & 0.18 \\
\hline $0.35 \times \mathrm{NaHCO}_{3}$ & 2.98 & 0.41 & 0.08 & 0.22 \\
\hline $0.44 \times \mathrm{NaHCO}_{3}$ & 3.05 & 0.39 & 0.07 & 0.26 \\
\hline $0.17 \times \mathrm{Na}_{2} \mathrm{SO}_{4}$ & 2.11 & 0.21 & 0.15 & 0.29 \\
\hline $0.26 \times \mathrm{Na}_{2} \mathrm{SO}_{4}$ & 2.48 & 0.24 & 0.61 & 0.13 \\
\hline $0.35 \times \mathrm{Na}_{2} \mathrm{SO}_{4}$ & 2.98 & 0.33 & 0.06 & 0.20 \\
\hline $0.44 \times \mathrm{Na}_{2} \mathrm{SO}_{4}$ & 2.93 & 0.35 & 0.08 & 0.24 \\
\hline SEM & 0.21 & 0.04 & 0.02 & 0.02 \\
\hline ANOVA & \multicolumn{4}{|c|}{ __ Probability ____ } \\
\hline $\mathrm{Na}$ & 0.01 & NS & NS & 0.001 \\
\hline $\mathrm{Na}_{\llcorner}$ & 0.002 & NS & 0.02 & NS \\
\hline $\mathrm{Na}_{\mathrm{Q}}$ & NS & NS & NS & 0.01 \\
\hline Salt & NS & $\leq 0.001$ & NS & NS \\
\hline Salt $\times \mathrm{Na}$ & NS & 0.03 & NS & 0.001 \\
\hline
\end{tabular}

NS - Non-significant.

${ }^{1} \%$ of dressed weight (with organ weights).

$\mathrm{Na}_{\mathrm{L}}$ and $\mathrm{Na}_{\mathrm{Q}}$ are linear and quadratic terms for $\mathrm{Na}$, respectively.

Organ weights of the proventriculus, heart, liver, pancreas, gall bladder, lungs, and intestinal and shank lengths were measured and found to be non-significant (data not shown). In contrast, weights (\% of dressed weight) of gizzard, kidney, spleen and bursa significantly changed (Table 4). Gizzard weight was increased linearly with increasing levels of $\mathrm{dNa}$ from 0.17 to $0.44 \%$ ( $\mathrm{P} \leq 0.002$; main effect). The increased weight of the gizzard reflects the increasing digestive or metabolic capacity of birds. Kidney weight was almost double the lowest level of $\mathrm{dNa}$ in the case of $\mathrm{NaHCO}_{3}$ when compared with the lowest level of $\mathrm{Na}_{2} \mathrm{SO}_{4} \quad(\mathrm{p} \leq 0.03$; interaction effect). This suggests the bicarbonate buffer system mainly determines blood acid-base balance for optimal production performance and functions under regulatory control of the kidneys [14]. 
Kidney weight is indicates broiler dietary nutrient insufficiencies [34] or the presence of anti-nutritional factors $[35,36]$. In the present study, the acid base imbalance might cause the higher kidney weight. A linear increase in $\mathrm{dNa}$ decreased spleen weight $(\mathrm{p} \leq 0.02)$. The interaction (source $\times$ level) effect influenced the bursa weight $(\mathrm{p} \leq$ 0.001 ). The low weight of the spleen was observed at $0.35 \% \mathrm{dNa}$. The low weight of the bursa was observed at $0.26 \% \mathrm{dNa}$ for both salt sources. As the spleen and bursa are associated with immune function (as lymphoid organs) this may explain the poor DP at these levels.

\section{Conclusions}

Birds showed increased breast and thigh meat yield, and increasing capacity of the gizzard at higher levels of dietary sodium. In contrast, a reduced dressing percentage with increasing supplementation of dietary sodium was unclear. Lower levels of dietary sodium were sufficient for supporting immune organs (bursa and spleen). Therefore a verification of requirements by changing other electrolytes $\left(\mathrm{K}^{+}\right.$and $\left.\mathrm{Cl}^{-}\right)$, keeping a constant DEB level, and changing salt sources is suggested.

\section{Competing interests}

The authors declare that they have no competing interests.

\section{Authors' contributions}

RP and JK participated in the design of the study and did the farm visits and clinical investigations. MMHM performed the statistical analysis. All authors helped to draft the manuscript, and all authors read and approved the final manuscript.

\section{Acknowledgements}

This experiment was conducted and sponsored by the Research Model Broiler Unit at the Poultry Research and Training Center (University of Veterinary and Animal Sciences, Pakistan). All data collection of carcass and body characteristics was facilitated by students of BS (Hons) Poultry Science, Batch (2007-2011). The contributions of Zulfiqar Ali (Ex-Nutritional Consultant, Big Feeds (Pvt) Ltd, Lahore, Pakistan) in experimental diet formulation, preparation, and analyses are highly appreciated. This study was supported by Cooperative Research Program for Agriculture Science and Technology Development (Project No. PJ009422), Rural Development Administration, Republic of Korea. Higher Education Commission, Pakistanalso supported study financially.

Received: 7 April 2014 Accepted: 7 April 2014

Published: 15 May 2014

\section{References}

1. Mongin P: Electrolytes in nutrition. A review of basic principles and practical applications in poultry and swine. Orlando, FL: Proceedings of 3rd Annul International Minerals Conference; 1980:1.

2. Leeson S, Summers JD: Scott's Nutrition of the Chicken. 4th edition. Guelph, Ontario, Canada: University Books; 2001.

3. Fletcher T: Natural resources of Pakistan. 2011. http://insider.pk/national/ natural-resources-of-pakistan/.

4. Rondon EOO, Murakami AE, Furlan AC, Garcia J: Exigenciasnutricopmaos de sodio e cloro e estimativa do melhor balance electrolitico da racao para frangos de corte na fasepre-inicial (1-7 dias de idade). Rev Bras Zoot 2000, 29:1162-1166.

5. Borges SAAV, Fischer da Silva ADA, Meira T, Moura AM, Ostrensky A: Electrolyte balance in broiler growing diets. Intl J Poult Sci 2004, 3:623-628.

6. Mushtaq T, Sarwar M, Nawaz H, Mirza MA, Ahmad T: Effect and interactions of dietary sodium and chloride on broiler starter performance (hatching to twenty-eight days of age) under subtropical summer conditions. Poult Sci 2005, 84:1716-1722.

7. Mushtaq T, Mirza MA, Athar M, Hooge DM, Ahmad T, Ahmad G, Mushtaq $\mathrm{MMH}$, Noreen U: Dietary sodium and chloride for twenty-nine to forty-two-day-old broiler chickens at constant electrolyte balance under subtropical summer conditions. J Appl Poult Res 2007, 16:161-170.

8. Sharma ML, Gangwar PC: Electrolyte changes in the blood plasma of broilers as influenced by cooling during summer. Int'I J Biometeorol 1987, 31(3):211-216.

9. Smith MO, Teeter RG: Practical application of potassium chloride and fasting during naturally occurring summer heat stress. Poult Sci 1988, 67(Suppl. 1):36. Abstr.

10. Borges SA, Fischer da Silva AV, Majorka A, Hooge DM, Cummings KR: Physiological responses of broiler chickens to heat stress and dietary electrolyte balance (sodium plus potassium minus chloride, milliequivalents per kilogram). Poult Sci 2004, 83:1551-1558.

11. Johnson RJ, Karunajeewa $\mathrm{H}$ : The effects of dietary minerals and electrolytes on the growth and physiology of the young chick. J Nutr 1985, 115:1680-1690.

12. Teeter RG, Smith MO, Owens FN, Arp SC, Sangiah S, Breazile JE: Chronic heat stress and respiratory alkalosis, Occurrence and treatment in broiler chicks. Poult Sci 1985, 64:1060-1064.

13. Gorman I, Balnave D: Effects of dietary mineral supplementation on the performance and mineral excretions of broilers at high ambient temperatures. Br Poult Sci 1994, 35:563-572.

14. Hooge DM: Practicalities of using dietary sodium and potassium supplements to improve poultry performance. Proceedings of Arkansas Nutrition Conference. 2003:19.

15. Ahmad T, Sarwar M, Mahr-un-Nisa, Ahsan-ul-Haq, Zia-ul-Hasan: Influence of varying sources of dietary electrolytes on the performance of broilers reared in a high temperature environment. Anim Feed Sci Technol 2005, 120:277-298.

16. Ahmad T, Sarwar M: Dietary electrolyte balance, Implications in heat stressed broilers. Worlds Poult Sci J 2006, 62:638-653.

17. Ruiz-Lopez B, Austic RE: The effects of selected minerals on acid-base balance of growing chicks. Poult Sci 1993, 72:1054-1062

18. Whiting TS, Andrews LD, Stamps L: Effects of sodium bicarbonate and potassium chloride drinking water supplementation. 1. Performance and exterior carcass quality of broilers grown under thermoneutral or cyclic heat-stress conditions. Poult Sci 1991, 70:53-9.

19. Pourreza J, Edriss MA: The effects of high vs. normal temperatures on the physical characteristics of the broilers carcass. J Agric Sci Technol 1992, 1:35-41.

20. Karunajeewa $\mathrm{H}$, Barr DA, Fox M: The effects of high vs. normal temperatures on the growth performance of broiler chickens. Br Poult Sci 1986, 27:601-612

21. Borges SA, Ariki J, Martins JCL, De-Moraes VMB: Potassium chloride supplementation in heat stressed broilers. Rev Bras Zool 1999, 28:313-319.

22. Hubbard: Broiler Management Guide. Duluth, GA: Hubbard LLC; 2004.

23. AOAC: Official Methods of Analysis. 18th edition. Gaithersburg, MD: Association of Official Analytical Chemists; 2005.

24. Lacroix RL, Keeney DR, Welsh LM: Potentiometric titration of chloride in plant tissue extracts using the chloride ion electrode. Commun Soil Sci Plant Anal 1970, 1:1-6.

25. NRC: Nutrient Requirements of Poultry. 9 Revisedth edition. Washington, DC: National Academic Press; 1994.

26. Han $Y$, Baker DH: Digestible lysine requirement of male and female broiler chicks during the period three to six weeks post-hatching. Poult Sci 1994, 73:1739-45.

27. Suresh BN, Reddy BSV, Manjunatha PBH, Jaishankar N: Carcass Characteristics of Broilers Fed Sugarcane Press Residue with Biotechnological Agents. Int J Poult Sci 2009, 8(7):671-676.

28. Borges SA, Fischer da Silva AV, Ariki J, Hooge DM, Cummings KR: Dietary electrolyte balance for broiler chickens under moderately high ambient temperatures and relative humidities. Poult Sci 2003, 82:301-308.

29. Socha MT, Ensley SM, Tomlinson DJ, Johnson B: Variability of water consumption and potential impact on animal performance. Proceedings of California Animal Nutrition Conference; 2002:81-91.

30. Borges SA, Fischer da Silva AV, Ariki J, Hooge DM, Cummings KR: Dietary electrolyte balance for broiler chickens exposed to thermoneutral or heat ${ }^{-}$stress environments. Poult Sci 2003, 82:482-435. 
31. Good B: Water quality affects poultry production. Poult Dig 1985 44(517):108-109.

32. Grizzle JT, Armbrust MB, Saxton A: Water quality I, The effect of water nitrate and pH on broiler growth performance. J Appl Poult Res 1996, 5:330-336.

33. Water and Electrolytes (\& lodine), Sec. 4. In Animal Nutrition Handbook. 2 revth edition. Edited by Chiba LI. Auburn University Press, ALabama; 2009.

34. Carew L, Mcmurtry J, Alster F: Effects of lysine deficiencies on plasma levels of thyroid hormones, insulin-like growth factors I and II, liver and body weights, and feed intake in growing chickens. Poult Sci 2005, 84:1045-1050.

35. Bailey CA, Stipanovic RD, Ziehr MS, Haq AU, Sattar M, Kubena LF, Kim HL, Vieira RD: Cottonseed with a high (+) to (-)-gossypol enantiomer ratio favorable to broiler production. J Agric Food Chem 2000, 48:5692-5695.

36. Farran MT, Halaby WS, Barbour GW, Uwayjan MG, Sleiman FT, Ashkarian VM: Effects of feeding ervil (Viciaervilia) seeds soaked in water or acetic acid on performance and internal organ size of broilers and production and egg quality of laying hens. Poult Sci 2005, 84:1723-1728.

doi:10.1186/2055-0391-56-4

Cite this article as: Mushtaq et al:: Carcass and body organ

characteristics of broilers supplemented with dietary sodium and

sodium salts under a phase feeding system. Journal of Animal Science and Technology 2014 56:4.

\section{Submit your next manuscript to BioMed Central and take full advantage of:}

- Convenient online submission

- Thorough peer review

- No space constraints or color figure charges

- Immediate publication on acceptance

- Inclusion in PubMed, CAS, Scopus and Google Scholar

- Research which is freely available for redistribution 